\title{
NOVEL PLANT GROWTH REGULATORS FOR MEDICAL CHEMISTRY
}

\section{A. Lifintseva' ${ }^{1}$ A. Yurkovskaya' , A. Kalistratova', M. Oshchepkov'1,}

M. Ivanova', N. Bystrova ${ }^{2}$, M. Akimov ${ }^{3}$, K. Kochetkov² and L. Kovalenko'

${ }^{1}$ CFT Faculty, Mendeleev University of Chemical Technology of Russia, 125047, Russian Federation, Moscow, Miusskaya square, 9.

${ }^{2}$ Lab. Homolytic Reactions of Organoelement Compounds, INEOS RAS, 119991, Russian Federation, Moscow, Vavilova St., 28.

${ }^{3}$ M. M. Shemyakin - Yu. A. Ovchinnikov Institute of Bioorganic Chemistry RAS, 117997, Russian Federation, Moscow, Miklukho-Maklaya St., 16/10.

DOI: 10.19163/MedChemRussia2021-2021-390

E-mail: nlifintseva1406@gmail.com

Phytohormones have a wide range of biological activity both in plants and in animals. For example, there is the anti-aging and anti-cancer activity of cytokinins, which have already found application in cosmetology [1].

We have synthesized a large number of synthetic derivatives of arylsubstituted urea with cytokinin-like activity which are interesting and promising easily synthesized plant growth regulators, suitable for use in agriculture [1-3].<smiles>O=C(Nc1ccccc1)Nc1ccnc(Cl)c1</smiles><smiles>O=C(NCCN1CCNC1=O)Nc1ccccc1</smiles><smiles>CC(C)OC(=O)NCCOC(=O)Nc1ccc(Cl)cc1</smiles>

Known plant growth regulators<smiles>[R]c1ccc(NC(=O)Nc2ccnc(Cl)c2)cc1</smiles><smiles>[R]c1ccccc1NC(=O)OCCN1CCNC1=O</smiles><smiles>[R]c1cccc(NC(=O)[X]CCNC(=O)C(=O)O[Na])c1</smiles>

Novel plant growth regulators

A number of the obtained substances were tested for anti-cancer and antioxidant activity on animal cells. Among them, pyridyl substituted urea is interesting as new anti-cancer substances, and ethylene-bis-urea derivatives are attracting as protectors against oxidative stress and hypoglycemia.

This work was supported by the Russian Foundation for Basic Research (grant no. 19-03-00492 A).

\section{References}

[1] M. Oshchepkov, A. Kalistratova, E. Savelieva et.al., Russian Chemical Reviews. 2020, 89-8, 787-810.

[2] A. Kalistratova, L. Kovalenko, M. et.al., Bulgarian Journal of Agricultural Science. 2019, 26-4, 772-776.

[3] A. Kalistratova, L. Kovalenko, M. Oshchepkov et.al., Journal of Mendeleev Communication. 2020, 30-2, 153-156. 